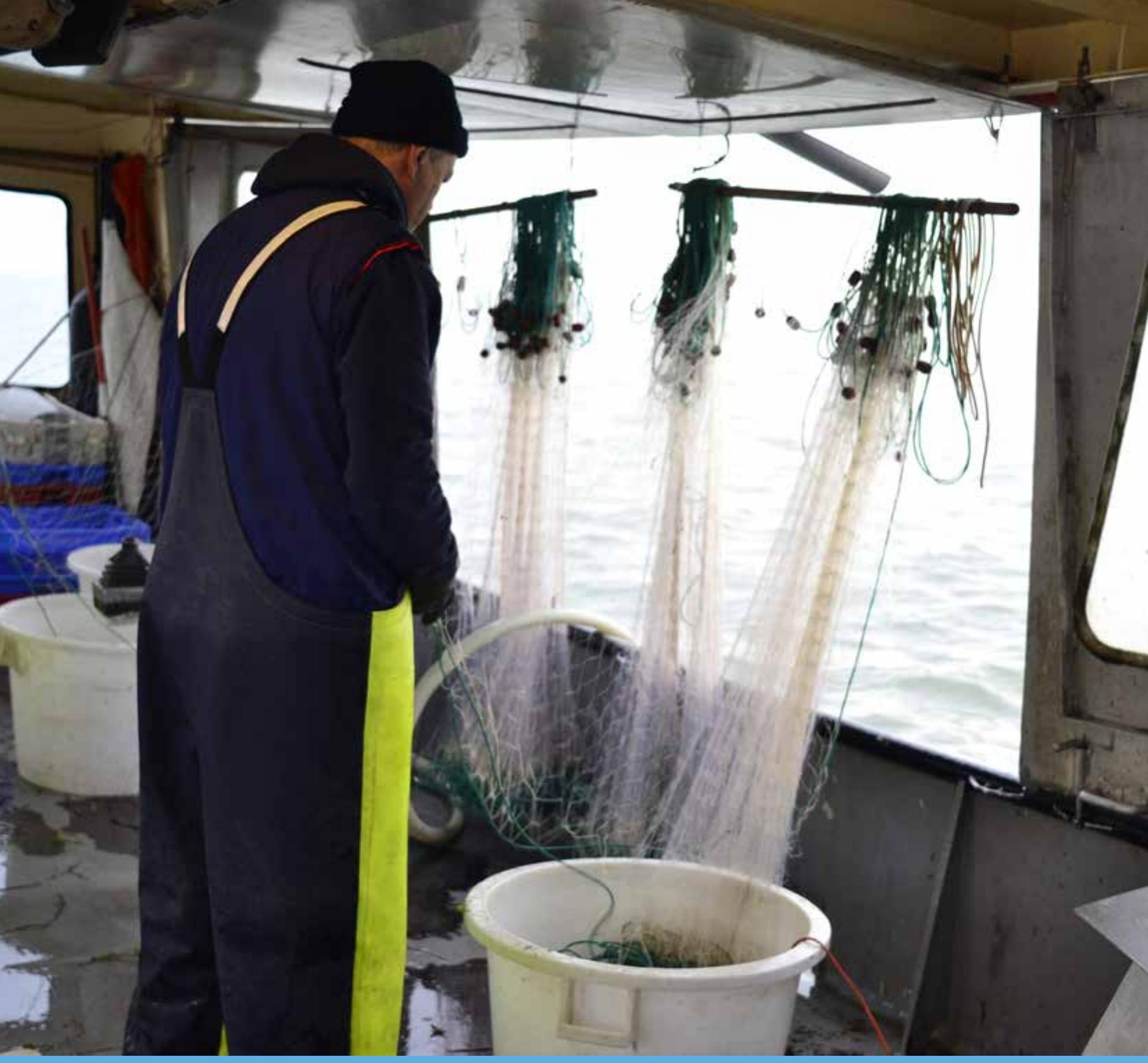

Overgangstermijn innemen ongebruikte rechten voor staande netten IJsselmeervisserij

Wim Zaalmink, Henri Prins en Bas Janssens

WAGENINGEN UNIVERSITY \& RESEARCH 



\section{Overgangstermijn innemen ongebruikte rechten voor staande netten IJsselmeervisserij}

Wim Zaalmink, Henri Prins en Bas Janssens

Dit onderzoek is uitgevoerd door Wageningen Economic Research in opdracht van en gefinancierd door het ministerie van Landbouw, Natuur en Voedselkwaliteit, in het kader van het Beleidsondersteunend onderzoeksthema 'Verduurzaming Visserij' (projectnummer BO-20-010-162)

Wageningen Economic Research

Wageningen, januari 2019

NOTA

2019-006 
Zaalmink, Wim, Henri Prins en Bas Janssens, 2019. Overgangstermijn innemen ongebruikte rechten voor staande netten IJsselmeervisserij. Wageningen, Wageningen Economic Research, Nota 2019-006. 20 blz.; 0 fig.; 3 tab.; 14 ref.

De rechten voor staande netten die gebruikt mogen worden voor de schubvisvisserij op het IJsselmeer zijn sinds 2014 gereduceerd met $85 \%$. De sindsdien niet gebruikte rechten brengen bij uitgifte en controle onnodige administratieve lasten met zich mee, zijn daarmee foutgevoelig en kunnen leiden tot een niet realistische beeldvorming over toekomstig gebruik in de visserijpraktijk.

Daarom overweegt de minister van Landbouw, Natuur en Voedselkwaliteit (LNV) maatregelen te treffen om deze rechten in te nemen. De vraag is of vissers hier schade van ondervinden, of er een balans is tussen enerzijds het ondernemersbelang en anderzijds het maatschappelijke belang, en welke overgangstermijn passend is om deze maatregelen in te laten gaan.

Trefwoorden: IJsselmeervisserij, rechten voor staande netten, wetgeving, regulering

Dit rapport is gratis te downloaden op https://doi.org/10.18174/467979 of op www.wur. nl/economicresearch (onder Wageningen Economic Research publicaties).

(C) 2019 Wageningen Economic Research

Postbus 29703, 2502 LS Den Haag, T 07033583 30, E communications.ssg@wur.nl, www.wur.nl/economic-research. Wageningen Economic Research is onderdeel van Wageningen University \& Research.

\section{(cc) BY-NC}

Wageningen Economic Research hanteert voor haar rapporten een Creative Commons Naamsvermelding 3.0 Nederland licentie.

(C) Wageningen Economic Research, onderdeel van Stichting Wageningen Research, 2019

De gebruiker mag het werk kopiëren, verspreiden en doorgeven en afgeleide werken maken. Materiaal van derden waarvan in het werk gebruik is gemaakt en waarop intellectuele eigendomsrechten berusten, mogen niet zonder voorafgaande toestemming van derden gebruikt worden. De gebruiker dient bij het werk de door de maker of de licentiegever aangegeven naam te vermelden, maar niet zodanig dat de indruk gewekt wordt dat zij daarmee instemmen met het werk van de gebruiker of het gebruik van het werk. De gebruiker mag het werk niet voor commerciële doeleinden gebruiken.

Wageningen Economic Research aanvaardt geen aansprakelijkheid voor eventuele schade voortvloeiend uit het gebruik van de resultaten van dit onderzoek of de toepassing van de adviezen.

Wageningen Economic Research is ISO 9001:2008 gecertificeerd.

Wageningen Economic Research Nota 2019-006 | Projectcode 2282300238

Foto omslag: Michiel Dammers/Wageningen University \& Research 


\section{Inhoud}

$\begin{array}{ll}\text { Samenvatting } & 5\end{array}$

$\begin{array}{llr}1 & \text { Inleiding } & 6\end{array}$

1.1 Aanleiding 6

1.2 Vraagstelling 6

$\begin{array}{lll}1.3 & \text { Leeswijzer } & 6\end{array}$

$2 \quad$ Ontwikkelingen van het gebruik van rechten voor staande netten 7

$\begin{array}{llr}3 & \text { Regulering van rechten voor staande netten } & 10\end{array}$

$4 \quad$ Overgangstermijn tussen afkondigen en ingaan maatregel 12

4.1 Deelvragen 12

4.2 Wetgeving en overgangstermijnen 12

$\begin{array}{lll}4.3 & \text { Inkomensverlies en vermogensafname } & 13\end{array}$

4.3.1 Inkomen 13

4.3.2 Vermogenseffecten 13

$\begin{array}{lll}4.4 & \text { Verschillen tussen bedrijven } & 15\end{array}$

$\begin{array}{lll}4.5 & \text { Overige neveneffecten } & 15\end{array}$

$5 \quad$ Toekomstige visserij-inspanning in het IJsselmeer $\quad 16$

$\begin{array}{llr}6 & \text { Conclusies } & 18\end{array}$

$\begin{array}{ll}\text { Literatuur en websites } & 19\end{array}$ 



\section{Samenvatting}

De rechten voor staande netten die gebruikt mogen worden voor de schubvisvisserij op het IJsselmeer zijn sinds 2014 gereduceerd met $85 \%$. Er is een aanzienlijk deel van deze rechten dat overbodig is, omdat deze niet ingezet mogen worden. Deze rechten brengen bij uitgifte en controle onnodige administratieve lasten met zich mee, zijn daarmee foutgevoelig en kunnen leiden tot een niet realistische beeldvorming over toekomstig gebruik in de visserijpraktijk.

\section{Afname visserij-inspanning nodig}

Voor het realiseren van de langetermijndoelstellingen voor een duurzaam beheer van de schubvisbestanden in het IJsselmeer is een afname van de visserij-inspanning noodzakelijk. Daarnaast is de Wet natuurbescherming van belang die de visplannen toetst aan de Natura 2000-doelstellingen. Het is zeer waarschijnlijk dat de toegestane visserij-inspanning voor het IJsselmeer en het Markermeer niet hoger zal worden dan de huidige toegestane inspanning. Daarom overweegt de minister van Landbouw, Natuur en Voedselkwaliteit (LNV) maatregelen te treffen om de niet-gebruikte rechten voor staande netten in te nemen. De vraag is of vissers hier schade van ondervinden, of er een balans is tussen het ondernemersbelang enerzijds en het maatschappelijke belang anderzijds, en welke overgangstermijn passend is om deze maatregelen in te laten gaan.

\section{Economische waarde blijft intact}

Het innemen van een deel van de rechten voor staande netten heeft een zeer beperkte invloed op de eigendomswaarde van bedrijven en resterende rechten. Deze behouden hun economische waarde en daarmee ook de waarde bij verhandeling. Regulering van eigendom is toegestaan onder bepaalde voorwaarden. Eén van de voorwaarden is dat er een 'fair balance' moet zijn tussen het algemene belang en het individuele belang. Daarom is in het algemeen een overgangstermijn noodzakelijk om ondernemers de gelegenheid te bieden de onderneming aan te passen aan de gewijzigde omstandigheden.

Bij het innemen van niet gebruikte rechten voor staande netten is een overgangstermijn van 5 tot 7 jaar tussen afkondiging en van kracht worden (ingaan) van een maatregel voldoende. Hierbij wordt geadviseerd om na deze overgangsperiode alleen die aantallen rechten in te nemen die tijdens deze periode niet meer toegestaan zijn. 


\section{$1 \quad$ Inleiding}

\section{$1.1 \quad$ Aanleiding}

De visserij in het IJssel- en Markermeer (hierna: IJsselmeer) wordt gereguleerd door vergunningen en daaraan gekoppeld de rechten op inzet van vistuigen, waaronder staande netten. Elk vergund vistuig dient bij gebruik voorzien te zijn van een merkje met een vistuigspecifieke kleur en uniek nummer. De eenheid per vergund staand net wordt in de praktijk dan ook uitgedrukt in merkjes, waarbij één merkje staat voor een net met een maximale lengte van 100 meter. Voor het gebruik van deze staande netten zijn op dit moment (2018) 4.000 rechten beschikbaar, in hoeveelheden van 50 stuks of een veelvoud daarvan (bron: RVO). In de volksmond wordt ook wel gesproken over merkjes. Het inzetbare aantal rechten voor staande netten wordt jaarlijks bepaald, en in de jaarlijkse vergunning die aan elke visser wordt afgegeven specifiek aangegeven. In 2014 is door de overheid een reductie ingevoerd van $85 \%$ van het aantal te gebruiken rechten voor staande netten. De reden hiervan was dat de schubvisbestanden (snoekbaars, baars, brasem, blankvoorn) dusdanig in omvang waren afgenomen dat een maximering van de visserij-inspanning nodig was om het risico op verdere achteruitgang van de bestanden te voorkomen. Met de invoering van deze maatregel mogen vissers maximaal $15 \%$ (= 600 rechten) inzetten van het totaal aantal rechten dat beschikbaar is. De ontwikkeling van de schubvisbestanden heeft na 2014 geen aanleiding gegeven tot aanpassing van de ingevoerde reductiemaatregel en de verwachting is dat dit ook in de toekomst niet het geval zal zijn. Het jaarlijks uitgeven en controleren van de merkjes leidt tot een behoorlijke administratieve en handhavingsinspanning. Merkjes zijn individueel genummerd en wanneer een groot deel hiervan niet gebruikt wordt, is de kans op vergissingen en fouten groter bij zowel de uitgifte als bij de controle in het veld (lees: water). Dit kan dan leiden tot inefficiënte en foutgevoelige handhaving. Het is dan ook niet gewenst dat de feitelijke en juridische situatie verschillend is. Daarnaast kan deze situatie in de visserijpraktijk leiden tot een verkeerde beeldvorming en niet realistisch verwachtingspatroon over de toekomstige inzet van de 'overbodige' merkjes.

\subsection{Vraagstelling}

Omwille van vereenvoudiging van administratie en handhaving wil de minister van Landbouw, Natuur en Voedselkwaliteit (hierna: LNV) overgaan tot het definitief innemen van de ongebruikte rechten voor staande netten. Hiervoor is een afkondiging nodig, waarbij de volgende vragen aan de orde zijn:

a. Wat is de schade voor vissers bij het innemen van ongebruikte rechten voor staande netten,

b. Is er een fair balance tussen ondernemersbelang en algemeen maatschappelijk belang,

c. welke termijn is noodzakelijk tussen de afkondiging van de maatregel en het ingaan van de maatregel?

\subsection{Leeswijzer}

In hoofdstuk 2 worden de huidige ontwikkelingen rondom de staande netten en de rechten ervan beschreven. Het volgende hoofdstuk (3) gaat in op de regulering en juridische consequenties van het innemen van rechten voor staande netten, en er worden vergelijkbare casussen in andere (landbouw)sectoren beschreven.

In hoofdstuk 4 wordt nagegaan welke overgangstermijn passend is gegeven de situatie en wordt gekeken naar de gevolgen van het innemen van de niet-benutte rechten voor staande netten: zijn er economische consequenties, is er een vermogensafname? Omdat het innemen afhankelijk is van ecologische ontwikkelingen in en rondom het IJsselmeer wordt in hoofdstuk 5 aandacht besteed aan de mogelijke toekomstige visbestandsontwikkelingen. Hoofdstuk 6 bevat de conclusies van het onderzoek. 


\section{Ontwikkelingen van het gebruik van rechten voor staande netten}

Om te mogen vissen met (onder meer) staande netten, dienen beroepsvissers te beschikken over geldige vergunningen. Dit betekent dat iedere beroepsvisser op het IJsselmeer voor het uitoefenen van zijn beroep in het bezit moeten zijn van zowel een geldige vergunning op grond van de Visserijwet 1963 (hierna ook wel: visserijvergunning) als een geldige vergunning op grond van de Wet natuurbescherming (Wnb); de laatste vergunning is nodig omdat het IJsselmeer is aangewezen als Natura 2000-gebied. Beide vergunningen hebben een geldigheidsduur van één jaar.

De visserij met staand net in het IJsselmeer wordt door de minister van LNV gereguleerd door de uitgifte van vergunningen aan vergunninghouders met daaraan gekoppelde individueel genummerde aantallen rechten voor staande netten. Deze vergunning wordt, conform artikel 73, tweede lid, van de Uitvoeringsregeling visserij jaarlijks verleend aan ondernemers die op 31 mei 1996 om 24.00 uur over een vergunning voor IJsselmeervisserij beschikten. De hoeveelheid rechten op de visserijvergunning worden, conform artikel 73, derde lid, van de Uitvoeringsregeling visserij, vastgesteld met inachtneming van de historische rechten van de visser gedurende het visseizoen 1995/1996. Het aantal netten dat daadwerkelijk mag worden ingezet wordt jaarlijks vastgesteld, mede aan de hand van het aantal historische rechten dat iemand heeft. Wageningen Marine Research (WMR) monitort de omvang van de schubvisbestanden en adviseert jaarlijks de minister van LNV over de gewenste visserij-inspanning.

De Wnb vervangt sinds 1 januari 2017 de Natuurbeschermingswet 1998, de Boswet en de Flora- en Faunawet. Om op het IJsselmeer te mogen vissen met staande netten, dient iedere visser naast de door RVO namens de minister van LNV afgegeven vergunning op grond van de Visserijwet 1963 ook te beschikken over een aanvullende Wnb-vergunning voor de locatie(s) waar wordt gevist. Voor het IJsselmeer zijn de omliggende provincies Friesland, Noord-Holland en Flevoland bevoegd gezag voor de Wnb-vergunning. Iedere provincie verstrekt de Wnn-vergunning voor dat deel van het IJsselmeer waar het merendeel van de activiteiten plaatsvindt. De vergunning wordt voor een jaar verstrekt en dient elk jaar opnieuw aangevraagd te worden. De Wnb-vergunning voor de IJsselmeerberoepsvissers wordt collectief door de PO IJsselmeer aangevraagd. In de Wnb zijn onder andere doelstellingen voor de voor vis- en schelpdieretende watervogels en beschermde vissoorten gedefinieerd. Voor het verlenen van een Wnb-vergunning dient voor de voorgenomen activiteit middels een passende beoordeling te worden aangetoond dat deze activiteit de natuurlijke kenmerken van het betrokken gebied niet aantast. In de passende beoordelingen wordt voor de beschermde vogel- en vissoorten die in de staand want visserij mogelijk worden bijgevangen, beoordeeld of deze bijvangst een risico vormt voor het behalen van de doelstellingen zoals die in de Wnb zijn geformuleerd. Ook significant negatieve effecten op de voedselreservering voor visetende watervogels worden in de beoordeling betrokken.

\section{Gebruik van staand net}

Voor de visserij met staand net zijn op grond van de Visserijwet 19634.000 rechten beschikbaar in eenheden van 50 of een veelvoud daarvan (uitzonderingen daargelaten). In het jaar 2014 is door het ministerie van LNV besloten tot een $85 \%$ reductie van het gebruik van deze rechten als gevolg van teruglopende schubvisbestanden. Bij uitspraak van 26 april 2016 oordeelde de Afdeling Bestuursrechtspraak van de Raad van State dat de toenmalige Staatssecretaris van Economische Zaken bij de voorbereiding van de besluiten tot reductie van de schubvisvisserij onvoldoende rekening heeft gehouden met de belangen van vissers die met behulp van (aangepaste) staande netten alleen op wolhandkrab visten. Daarop is door de toenmalige Staatssecretaris van EZ besloten om toe te staan dat de overblijvende $85 \%$ van de rechten ingezet mag worden voor visserij op wolhandkrab met lage staande netten. Deze netten zijn voorzien van oranje merken.

Zwarte merken betreffen de $15 \%$ van het totaal op de vergunning vermelde aantal rechten voor staande netten dat ter beschikking van een visser staat, en deze $15 \%$ mogen zowel voor hoge 
staande netten (gestrekte maas, kieuwnet, voor visserij op schubvis) als voor lage staande netten (op de bodem warrelig 'opgevouwen', als kluwen gelegd, voor visserij op wolhandkrab) worden ingezet, dit naar keuze van de visser. Dit heet ook wel type 1 . De resterende $85 \%$ rechten op de vergunning worden geduid als type 2 ; deze netten mogen alleen laag worden geplaatst en hieraan moet een oranje merkje worden bevestigd. De maximale lengte van een net is in de vergunning vastgelegd op 100 meter. De hoogte varieert van maximaal 2 meter voor hoge netten en maximaal $40 \mathrm{~cm}$ voor lage netten en de minimale maaswijdte bedraagt $101 \mathrm{~mm}$.

Bij de aanvraag voor de Wnb-vergunning van PO IJsselmeer voor 2016/17 is het (maximale) aantal netnachten berekend waarin staande netten zouden kunnen worden ingezet zonder een significant negatief effect te hebben op het behalen van de doelstellingen aan vis- of schelpdieretende watervogels onder Natura 2000. Hieruit volgde dat naast de 15\% zwarte merken een additionele inzet van maximaal $15 \%$ oranje merken (type 2 ) mogelijk zou zijn.

Met ingang van het visserijseizoen 2017/2018 werd door WMR voor de visvergunning een aanvullende reductie van $36 \%$ geadviseerd. Omdat de IJsselmeervissers zich hierin niet konden vinden kwam PO IJsselmeer met een alternatief plan (plan 'B'), waarin onder meer een beperking tot 15\% (type 1, zwarte merkjes) was opgenomen zonder aanvullende inzet van oranje merkjes. Dit is toen ook als zodanig in de Wnb-vergunning (6 juli 2017, provincie Friesland) opgenomen. Voor het seizoen 2018/2019 hebben de onderscheiden provincies (Noord-Holland), Friesland en Flevoland expliciet in de Wnb-vergunning opgenomen dat geen aanvullende rechten voor staande netten type 2 (oranje, laag) mochten worden ingezet omdat er geen onderzoek was uitgevoerd naar het effect van lage netten op de bijvangst van vogels; een passende beoordeling op dit onderdeel ontbrak.

De uitspraak van de Raad van State over het gebruik van lage staande netten (oranje merkjes) was gedateerd op 26 april 2016. Dit betekent dat in de voorgaande visseizoenen 2014/2015 en 2015/2016 alleen met zwarte merkjes is gevist, en dat de $15 \%$ oranje merken (type 2 ) tot nu toe alleen in het visseizoen 2016/17 zijn ingezet.

Een overzicht van de verdeling en het gebruik van rechten voor staande netten in visseizoen $2016 / 2017$ is opgenomen in tabel 3.1.

Tabel 3.1 Overzicht van de verdeling en het gebruik van rechten voor staande netten in 2016/2017

\begin{tabular}{|c|c|c|c|}
\hline Vistuig/kleur merkje & $\begin{array}{l}\text { Uitgegeven rechten voor } \\
\text { staande netten }\end{array}$ & $\begin{array}{l}\text { Gebruikte rechten voor } \\
\text { staande netten in } 2016 / 17\end{array}$ & $\%$ ingezet \\
\hline $\begin{array}{l}\text { Staand net hoog (type } 1 \text {, } \\
\text { zwart) }\end{array}$ & 622 a) & $300-400$ & $48-64$ \\
\hline $\begin{array}{l}\text { Staand net laag (type } 2 \text {, } \\
\text { oranje) }\end{array}$ & $\begin{array}{c}3378, \text { waarvan } \\
622 \text { mogen worden gebruikt b) }\end{array}$ & $300-400$ & $9-12$ \\
\hline
\end{tabular}

a) Door omstandigheden is dit iets meer dan 15\% van 4.000; b) Bij de vergunningsaanvraag 2016/17 is door PO IJsselmeer uitgegaan van maximaal 20.500 merkweken

Bronnen: RVO (2016), Zaalmink et al. (2017).

Naast het feit dat een merkje een recht vertegenwoordigt om te mogen vissen, is dit in feite een fysiek plastic plaatje met een uniek nummer, wat ter identificatie aan een net (aan de bovenpees) moet worden bevestigd. Op de vergunning op grond van de Visserijwet 1963 van iedere visser staan de individuele nummers van de type 1 en type 2 geduide netten van de visser. Deze merkjes met unieke nummers worden met de vergunning verstrekt/uitgegeven door RVO.

De visrechten voor alle vistuigen voor het IJsselmeer worden vergund aan totaal 77 vergunningshouders (tabel 3.2). Van deze vergunninghouders is een deel (49) in het bezit van rechten voor staande netten, waarvan 6 seizoenvergunninghouders. 
Tabel 3.2 IJsselmeervisserij 2016: aantal vergunninghouders

\begin{tabular}{lcc} 
& Aantal & Aantal met vergunning staand want \\
Vergunninghouders & 77 & 49 \\
\hline Waarvan jaarvergunninghouders & 71 & 43 \\
\hline Waarvan seizoenvergunninghouders & 6 & 6 \\
\hline Bedrijven & 41 & 24 (eigendom +gehuurd-verhuurd) \\
\hline Actieve bedrijven (met geregistreerde aanlandingen) & 34 & 23 \\
\hline Actieve visserijondernemers & circa 59 & circa 44
\end{tabular}

Bron: Zaalmink et al. (2017). 


\section{Regulering van rechten voor staande netten}

Sinds 2014 is er een reductie van $85 \%$ van rechten voor staande netten met het oog op schubvis, met uitzondering van één jaar waarin aanvullend met maximaal $15 \%$ van de rechten voor staande netten op wolhandkrab (oranje, type 2, laag net) mocht worden gevist. Zoals in hoofdstuk 1 is weergegeven wil het ministerie van LNV de rechten die niet meer mogen worden gebruikt, definitief innemen, dit vanwege de administratieve lastendruk, de inefficiënte, gevoelige handhaving, de beeldvorming en het verwachtingspatroon bij vissers wanneer de niet gebruikte rechten toch voortdurend 'in de lucht' blijven hangen.

Voor de uitvoering van de visserij op het IJsselmeer is een vergunning noodzakelijk (artikel 8 van het Reglement voor de binnenvisserij 1985). Op deze vergunning zijn de soort(en) en de aantallen netten opgenomen, waarmee gevist mag worden (in dit geval de rechten voor staande netten). Het definitief verminderen van het aantal rechten op de vergunning, levert een beperking op van het gebruik van het onderliggende eigendom waar de vergunning betrekking op heeft, in casu het visserijbedrijf en de daarmee gepaard gaande economische belangen. Het innemen van een deel van deze rechten betekent echter niet dat de bedrijven hun waarde verliezen. Immers de bedrijven kunnen hun activiteiten voorzetten, de vergunning, resterende rechten en fysieke bedrijfsmiddelen kunnen nog steeds gebruikt en verhandeld worden. Daarom is er regulering van eigendom.

Een voorbeeld voor het beperken van een deel van de productierechten is de Wet herstructurering varkenshouderij. Deze wet is ingegaan per 1 september 1998. Doel was het verminderen van de mestproductie van varkens. Om dit doel te bereiken werd onder andere een stelsel van varkensrechten ontwikkeld, en bedoeling was dat deze varkensrechten vervolgens met $25 \%$ zouden worden gekort. De varkenshouders gingen hiertegen in beroep omdat zij meenden dat de maatregelen een ontneming van eigendom waren en daarmee in strijd waren met onder andere artikel 1 Eerste Protocol (EP) van het Europese Verdrag tot bescherming van de Rechten van de Mens (EVRM). Het vervallen van een deel van de mestproductierechten moest in hun ogen gepaard gaan met een schadevergoeding door de overheid. De Hoge Raad oordeelde echter op 16 november 2001 dat er geen sprake was van onteigening, maar van regulering van eigendom. Om te bezien of er 'de facto onteigening' was, moet gekeken worden naar de effecten van de maatregel (in casu de korting) op het door die maatregel getroffen bedrijf in zijn geheel, in dit geval de varkenshouderij (Ogink et al., 2002).

Regulering van eigendom door de overheid is onder bepaalde voorwaarden toegestaan. Deze voorwaarden zijn opgenomen in artikel 1 van Eerste Protocol van het EVRM, en zijn als volgt (Schild, 2009):

a. De inbreuk moet bij de wet zijn voorzien. De wettelijke basis moet voldoende precies, toegankelijk en voorzienbaar zijn.

b. De inbreuk moet een gerechtvaardigd algemeen belang dienen.

c. De inbreuk dient proportioneel te zijn, dat wil zeggen dat er moet een 'fair balance' zijn tussen het algemene belang en de bescherming van de individuele rechten van het individu.

Een ontneming van eigendom zonder enige vorm van compensatie wordt als disproportioneel gezien. Er moet een fair balance zijn tussen het algemene belang en de grondrechten waarop inbreuk wordt gemaakt. Bij ontneming is het uitgangspunt een volledige schadevergoeding (Barkhuizen en Emmerik, 2003). Als het gaat om het reguleren van eigendom zijn de eisen om een fair balance te bereiken minder streng; een lange overgangstermijn kan voldoende compensatie geven waardoor een schadevergoeding niet meer nodig is.

Een ander voorbeeld met betrekking tot het innemen van productierechten is de Wet verbod pelsdierhouderij. Op 15 januari 2013 trad deze wet in werking, waarmee het houden en doden van pelsdieren werd verboden met ingang van 1 januari 2024. Deze overgangsperiode was bedoeld om de 
gedane investeringen ten behoeve van verbetering van het dierenwelzijn terug te verdienen en ter compensatie van schade. De betreffende periode werd lang genoeg geacht om pelsdierhouders de kans te geven over te kunnen schakelen naar andere sectoren. Naast deze overgangstermijn waren flankerende maatregelen opgenomen: (a) een tegemoetkoming in de kosten van sloop of ombouw van gebouwen, (b) een wijziging van de regeling rondom herinvesteringsreserve in de Wet op de inkomstenbelasting (boekwinst kan hierdoor belastingvrij worden gebruikt voor herinvestering) en (c) een hardheidsclausule voor de pensioenvoorziening van oudere nertsenhouders.

De Hoge Raad gaf in het arrest over deze kwestie op 16 december 2016 aan dat ook hier sprake was van eigendomsregulering in plaats van ontneming en dat er een redelijke mate van evenredigheid moet zijn tussen gebruikte middelen en het doel dat moet worden nagestreefd. Als er een individuele en buitensporige last is voor een individu wordt hier niet aan voldaan. De volgende zaken kunnen daarbij van belang zijn (Hoge Raad, attest Nederlandse Federatie van Edelpelsdieren):

a. Is er compensatie geboden voor de ondervonden schade? Bij regulering van eigendom geldt niet per se als uitgangspunt dat compensatie moet worden geboden. Compensatie is slechts een van de factoren die bij de beoordeling van proportionaliteit meespelen.

b. De mate waarin het gebruik van de eigendommen voor andere doeleinden nog mogelijk is.

c. De voorzienbaarheid van de maatregel die de eigendommen aantast. Hierbij spelen ook de ondernemersrisico's een rol.

d. Het bestaan van een overgangstermijn, die de eigenaar in staat moet stellen om schade beperkende maatregelen te nemen.

e. Het bestaan van een regeling voor hardheidsgevallen.

Bij de hiervoor genoemde voorbeelden is er een regulering van eigendom, waarbij er evenredigheid tussen de maatregelen en het doel moet zijn. De situatie betreffende het innemen van de ongebruikte rechten door IJsselmeervissers verschilt echter van voorgaande voorbeelden. De ongebruikte rechten leveren immers op dit moment geen productie (en dus geen economische waarde en of inkomen), en er is grote onzekerheid of dit in de toekomst nog gaat gebeuren (zie hoofdstuk 5) Hierdoor is de verwachting dat deze ongebruikte rechten ook geen handelswaarde meer hebben. Dit zou kunnen betekenen dat deze rechten per direct zouden kunnen worden ingenomen. De fysiek aanwezige netten blijven hun waarde behouden, want ze kunnen nog steeds gebruikt worden voor de $15 \%$ rechten, en zijn daarmee ook nog verhandelbaar.

De onzekerheden met betrekking tot ontwikkeling van schubvisbestanden en Wnb-vergunningen pleiten echter voor een overgangsperiode tussen afkondiging en ingaan van de maatregel, zodat op het moment van inname met aan zekerheid grenzende waarschijnlijkheid kan worden gesteld dat de rechten die tijdens de overgangsperiode niet meer zijn gebruikt ook in de toekomst niet meer gebruikt zullen gaan worden.

Uit jurisprudentie over artikel 1 EP bij het Europees Hof voor de Rechten van de Mens ${ }^{1}$ volgt dat toekomstige (en onzekere) inkomsten uit die bedrijfsmiddelen die worden ingenomen zoals grond, opstallen en bedrijfsinventaris niet bepalend zijn voor de lengte van de overgangstermijn. Dit geldt ook voor toekomstige inkomsten uit goodwill (zoals klantenbestanden) en voor de waarde van een onderneming die afhankelijk is van de (onzekere) toekomstige inkomsten.

Er moet echter wel een zekere periode zijn waarbij ondernemers het risico kunnen spreiden en/of de onderneming kunnen aanpassen aan andere sectoren (zie ook Barkhuysen en Emmerik, 2003).

1 Uitspraak Gerechtshof Den Haag (10-11-2015) betreffende Wet verbod pelsdierhouderij 


\section{$4 \quad$ Overgangstermijn tussen afkondigen en ingaan maatregel}

\subsection{Deelvragen}

Bij de beantwoording van de vraag met betrekking tot de lengte van de overgangstermijn tussen afkondigen en het ingaan van de maatregel zijn de volgende deelvragen van belang:

- Wat zegt de wetgeving over overgangstermijnen?

- Is er inkomensverlies en vermogensafname op de betreffende visserij bedrijven?

- Zo ja, is er dan disproportionaliteit, met andere woorden zijn er dan bedrijven/groepen van bedrijven die meer of minder getroffen worden?

- Wat is een redelijke termijn tussen afkondiging en uitvoering waarna geen schadelijke effecten meer kunnen worden verwacht?

\subsection{Wetgeving en overgangstermijnen}

Ten aanzien van de lengte van overgangstermijnen zijn de volgende voorbeelden illustratief:

In 2013 werd het Varkensbesluit van kracht met grote gevolgen voor de varkenshouderij. De aankondiging hiervan vond plaats in 2003. Met dit besluit werden nieuwe (welzijns)eisen gesteld aan de huisvesting van varkens. Varkenshouders werden via een overgangstermijn in de gelegenheid gesteld om de inrichting van stallen aan te passen aan de nieuwe eisen, waarbij rekening is gehouden met een afschrijvingsperiode van stalinrichting van 10 jaar.

De Verordening Welzijnsnormen nertsen 2003, die op 11 december 2003 werd vastgesteld en waarbij de pelsdierhouders tot 1 januari 2014 de gelegenheid kregen de noodzakelijke investeringen te verrichten om te voldoen aan de eisen van de verordening, kende ook een overgangstermijn van 10 jaar.

Bij het voorbeeld van de Wet verbod pelsdierhouderij, zoals beschreven in het vorige hoofdstuk, werd een overgangsperiode in acht genomen van half januari 2013 tot 1 januari 2024. Deze overgangsperiode van iets meer dan 10 jaar was bedoeld om de gedane investeringen ten behoeve van verbetering van het dierenwelzijn (Verordening welzijnsnormen nertsen) terug te verdienen en ter compensatie van schade. De betreffende periode werd lang genoeg geacht om schade beperkende maatregelen te kunnen nemen en/of om over te kunnen schakelen naar andere sectoren.

In al deze gevallen gaat het erom dat de overgangstermijn dusdanig lang is dat ondernemers geacht worden in staat te zijn om binnen deze periode passende maatregelen te kunnen nemen.

Deze voorbeelden geven aan dat een overgangstermijn noodzakelijk kan zijn om een fair balance te verkrijgen tussen het algemeen belang en het ondernemersbelang. De lengte van de overgangstermijn moet voldoende zijn om de ondernemer de kans te geven passende maatregelen te nemen. Dit geldt dus ook voor maatregelen bij de IJsselmeervisserij: vissers moeten voldoende de gelegenheid krijgen om de bedrijfssituatie aan te passen aan de veranderende omstandigheden. De vraag is echter welke omstandigheden veranderen en in welke mate. Hier wordt in de volgende paragrafen op ingegaan. 


\subsection{Inkomensverlies en vermogensafname}

\subsubsection{Inkomen}

De waarde van de zwarte en oranje merkjes is in een vorige studie berekend en staat in tabel 4.1 vermeld (bron: Zaalmink et al., 2017). Deze waarde is berekend met gemiddelde prijzen van 20132016. In deze tabel staan de toegevoegde waarde, de contante waarde en de vrije marktwaarde vermeld. De toegevoegde waarde is de opbrengstwaarde (besomming) minus gemaakte kosten als brandstof en dergelijke. Uit eerder onderzoek blijkt de toegevoegde waarde circa $65 \%$ te zijn van de besomming. De contante waarde wordt toegepast bij onteigeningssituaties; deze waarde wordt vastgesteld via een factor 8 maal de toegevoegde waarde. De vrije marktwaarde is de waarde in het vrije marktverkeer; hiervoor wordt de factor 5 gebruikt (Zaalmink et al., 2017). Opgemerkt moet worden dat het hier gaat om de waarde per vergund merkje. Niet alle merkjes zijn daadwerkelijk of gedurende de volledige periode inzetbaar, zodat de waarde per gebruikt (ingezet) merkje hoger zal zijn dan per vergund merkje.

Tabel 4.1 Besomming en contante warde per vergund vistuig/merkje (in euro per seizoen/jaar, gebaseerd op gemiddelde prijzen 2013-2016)

\begin{tabular}{|c|c|c|c|c|c|}
\hline Vistuig & Eenheid & Besomming & $\begin{array}{c}\text { Toegevoegde } \\
\text { waarde }\end{array}$ & $\begin{array}{l}\text { Contante } \\
\text { waarde }\end{array}$ & $\begin{array}{c}\text { Vrije } \\
\text { marktwaarde }\end{array}$ \\
\hline Staand net (hoog) & Per net a) & 1.621 & 1.053 & 8.428 & 5.267 \\
\hline
\end{tabular}

a) Een staand net mag maximaal 37 weken $(1$ juli-15 maart) $* 4$ nachten $=37$ merkweken ofwel 148 netnachten per seizoen/jaar worden ingezet.

Bron: Zaalmink et al. (2017).

Uit tabel 4.1 blijkt dat met een vergund hoog net gemiddeld 1.621 euro wordt besomd en met een laag net gemiddeld 46 euro. De vraag of er bij inname van ongebruikte rechten ook inkomensverlies is, is afhankelijk van de vraag of in de toekomst de niet meer gebruikte rechten ooit nog weer ingezet mogen worden. Uit hoofdstuk 5 blijkt dat er grote onzekerheid is of in de toekomst de ongebruikte rechten ooit nog ingezet mogen worden. Hierdoor is de verwachting dat deze ongebruikte rechten geen inkomen meer zullen genereren.

\subsubsection{Vermogenseffecten}

Het effect op vermogen kan het gevolg zijn van lagere opbrengsten/inkomsten, lagere verhandelingswaarde van rechten, of doordat in bezit zijnde vistuigen (netten) en rechten zelf niet meer gebruikt mogen worden en daarmee hun waarde hebben verloren. De opbrengsten/ inkomsten en de waarde van de rechten voor staande netten zijn in de voorgaande paragraaf uitgewerkt. Als op dit moment rechten voor staande netten worden verhandeld zou dit betekenen dat van de 100 rechten die verhandeld worden er 15 daadwerkelijk ingezet kunnen worden en dat de waarde in het economische verkeer dus ook hierop gebaseerd is. Dit is ook de wijze waarop RVO de rechten verwerkt en berekent naar gebruiker. Wanneer de 85 rechten definitief worden ingenomen blijft de economische waarde dus gebaseerd op de 15 resterende rechten, en is er dus geen waardevermindering.

Het innemen van niet gebruikte rechten voor staande netten betekent dat voor en na de inname evenveel netten gebruikt kunnen worden. Navraag bij een nettenleverancier (VIC Den Oever) leert dat een staand net (100 meter lang, maximaal 2 meter hoog) met een maaswijdte van $101 \mathrm{~mm}$ (meest gebruikt bij de schubvisvisserij) circa 225 euro inclusief btw kost. De levensduur is afhankelijk van de intensiteit van het gebruik en de vangsten; bij goede vangsten, en/of veel wolhandkrabben, gaan ze één jaar mee, in andere gevallen meerdere jaren. Reparatie heeft volgens de leverancier bij volop gebruikte netten weinig zin, omdat de kosten van repareren niet opwegen tegenover de nieuwkosten. De praktijk leert echter dat netten vaak worden gerepareerd in de nettenschuren in de 'stille' uren 
wanneer er weinig visserijactiviteiten plaatsvinden, en/of door (gepensioneerde) familieleden die dit in hun vrije tijd en onbezoldigd uitvoeren, dus tegen weinig kosten voor de visserijondernemer zelf. Over het algemeen gebruiken boekhouders voor fuiken en netten een afschrijvingstermijn van 5 tot 7 jaar. Echter, voor staande netten die in het IJssel- en Markermeer worden gebruikt gaat dit niet op. In de fiscale balansen van de IJsselmeervisserijbedrijven zijn in de meeste gevallen geen netten terug te vinden. Dit betekent dat netten fiscaal niet als roerende goederen gezien worden, maar als operationele kosten (klein materiaal) worden opgenomen in de jaarrekeningen.

In totaal zijn voor het IJsselmeer 4.000 merkjes voor staande netten beschikbaar. Onder de veronderstelling dat voor elk merkje één net aanwezig is, zal de nieuwwaarde van het totaal van deze netten $4.000 * 225=900.000$ euro bedragen. De gemiddelde waarde wordt verondersteld de helft hiervan te zijn, te weten 450.000 euro voor alle bedrijven samen. Hier kunnen nog bijkomen de waarde van de 'plastic' merkjes die aangeschaft moeten worden om de uitgezette netten te identificeren. Deze merkjes worden in principe eenmalig verschaft (aangekocht) en kosten circa 0,54 euro per stuk. De totale waarde hiervan bedraagt dan 2.160 euro.

Doordat bij de $85 \%$ reductie minder netten behoeven te worden ingezet, zullen er voorraden bestaande netten overblijven. Voor de berekening van deze voorraden wordt nu het begrip netjaren geïntroduceerd. Het aantal netjaren is de voorraad van netten uitgedrukt in het aantal jaren dat het totaal van deze netten nog gebruikt kan worden. Stel voor dat netten een gebruiksduur hebben van 2 jaar. Bij 4.000 aanwezige netten zijn er dan 2.000 stuks bijna nieuwe netten (die 1,5 jaar meekunnen) en 2.000 stuks 1,5 jaar oude netten (die nog een half jaar gebruikt kunnen worden). Het totaal aantal netjaren bedraagt dan $2.000 * 1,5+2.000 * 0,5=4.000$.

De gekozen uitgangssituatie van 4.000 netten met een reductie van $85 \%$ van de rechten betekent dat jaarlijks maximaal 600 hoge netten gebruikt worden. De periode waarin alle voorradige netten als hoog net zijn gebruikt bedraagt dan 4.000 netjaren gedeeld door 600 te gebruiken hoge netten is 6 tot $7(6,7)$ jaar. Oftewel, bij ongewijzigd beleid en reductie van $85 \%$ vanaf 2014 zal het tot en met eind 2020 duren voordat de bestaande voorraad netten is uitgeput. Dit onder de veronderstelling dat ondertussen ook geen nieuwe netten worden aangeschaft, de resterende voorraad volledig intact is en netten uitwisselbaar zijn. Bij een afschrijvingstermijn of gebruiksduur van 3 in plaats van 2 jaar betekent dit dat het 10 jaar zal duren voordat de voorraad is uitgeput.

Uitgaande van de huidige situatie is er geen kapitaalvernietiging bij het definitief innemen van de ongebruikte rechten voor staande netten, immers de bestaande netten behouden hun waarde, en kunnen nog steeds gebruikt worden voor de visserij. Wel is er een (relatief) grotere voorraad (en daarmee kapitaal). Gebruiksduur en de afschrijvingstermijn van de staand netten bepalen wanneer door vissers nieuwe investeringen in netten moeten worden gedaan.

Voor die bedrijven die de afgelopen 2 jaren lage netten hebben gebruikt voor de visserij op wolhandkrab, en daarbij de hoge staand netten hebben aangepast naar lage netten, zal de voorraad netten al eerder dan het jaar 2020 uitgeput zijn. Voor elk jaar dat naast de hoge ook nog 600 lage netten worden ingezet, wordt de termijn van 6-7 jaar circa één jaar korter.

Deze redenering kan ook opgaan voor andere maatregelen. Veronderstel dat er een maatregel zou worden afgekondigd waarbij de maaswijdte wordt gewijzigd van $101 \mathrm{~mm}$ naar bijvoorbeeld $110 \mathrm{~mm}$, dan zou bij afkondiging in 2018 de maatregel op 1 januari 2021 kunnen ingaan zonder dat vissers overbodige investeringen behoeven te doen, ook dit weer onder de veronderstelling dat de levensduur van een net maximaal 2 jaar is.

Hier komt bij dat in de huidige situatie met $85 \%$ beperking op rechten de overblijvende $15 \%$ nog steeds kunnen worden benut, waarbij ook de andere bedrijfs- en productiemiddelen die beschikbaar zijn, zoals kotter, bijboot, andere visbenodigdheden, nog steeds te gebruiken zijn en daarmee hun waarde dus niet hebben verloren. 


\subsection{Verschillen tussen bedrijven}

Definitieve inname van de ongebruikte rechten heeft geen gevolgen ten opzicht van de situatie na 2014, en dit betekent dat er ook geen groepen bedrijven zijn die hier meer of minder door worden getroffen. Wanneer deze inname ook de rechten voor laag stand net (oranje) betreft geldt hetzelfde. Na de uitspraak van de Afdeling Bestuursrechtspraak van de Raad van State (d.d. 26 april 2016), hebben slechts enkele vissers van dit recht gebruikgemaakt, maar in principe heeft elke visser met rechten voor staande netten de mogelijkheid gehad met lage netten te vissen.

\subsection{Overige neveneffecten}

Met de inname van de merkjes zullen de administratieve lasten afnemen, en mogelijk nemen ook de fraudekansen af. Andere neveneffecten kunnen niet worden benoemd. 


\section{$5 \quad$ Toekomstige visserij-inspanning in het IJsselmeer}

Indien de ongebruikte rechten voor staande netten definitief worden ingenomen, betekent dit dat deze rechten dus nooit meer ingezet kunnen gaan worden. Dit moet worden afgezet tegen de vraag hoe groot de kans is dat deze toch weer mogen worden gebruikt, m.a.w. is de vraag van belang of de visserij inspanning ooit nog weer op het niveau van voor het jaar 2014 mag komen.

De minister van LNV is in het kader van de Visserijwet 1963 verantwoordelijk voor duurzame visserij en wil komen tot een wetenschappelijk onderbouwd duurzaam beheer van de schubvisbestanden van snoekbaars, baars, blankvoorn en brasem. Om de langetermijndoelstellingen voor deze vier visbestanden te bepalen heeft het toenmalige ministerie van EZ daarom een document opgesteld: Toekomstbeeld visstand IJsselmeer/Markermeer - synthesedocument. Hierin wordt het gewenste toekomstbeeld voor de vier visbestanden geschetst, op basis van de verplichtingen die volgen uit de visserijwet en de EU Kaderrichtlijn Water. In dit document wordt voorgesteld om:

'Voor de vier commercieel beviste vissoorten een situatie na te streven waarbij binnen de geschetste termijn van ca. 15 jaar wordt toegewerkt naar een situatie waarbij sprake is van een evenwichtiger lengte-opbouw van de bestanden met meer grotere exemplaren en een groter aantal jaarklassen. Met de sturing hierop wordt tegelijk gerealiseerd dat wordt toegewerkt naar een toename van de (paai)bestanden en zal sprake zijn van een natuurlijker opbouw en samenstelling van de visstand. Hiermee wordt een stap gezet van de huidige behoudsdoelstellingen, naar een inzet gericht op een herstel van de situatie met een visstand met een omvang en samenstelling die past bij de draagkracht van het systeem.'

In opdracht van de minister van LNV worden door WMR jaarlijks inspanningsadviezen gerapporteerd. In het rapport Inspanningsadviezen voor snoekbaars, baars, blankvoorn en brasem in het IJssel/Markermeer (Tien et al., 2017) worden de vangstadviezen voor het seizoen 2017/2018 beschreven. Tien et al. (2017) komen tot de volgende conclusie:

\footnotetext{
'Samengevat vertonen brasem en blankvoorn consistent negatieve bestandsontwikkelingen. Deze ontwikkelingen zijn leidend in de inspanningsadviezen. Om verdere achteruitgang in alle vier bestanden te voorkomen wordt geadviseerd om de toegestane inspanning in de zegen- en staandwantvisserij te reduceren naar $64 \%$ t.o.v. de huidige hoeveelheid (die al met $85 \%$ gereduceerd is). Om de veel strengere doelstellingen zoals verwoord in het document "Toekomstbeeld visstand IJsselmeer/Markermeer - synthesedocument" na te streven, wordt een 0-vangst voor brasem geadviseerd en een vangstreductie voor blankvoorn naar $27 \%$. Voor snoekbaars en baars worden minder strenge maatregelen geadviseerd, omdat de signalen omtrent deze bestanden positiever zijn.'
}

Hier komt bij dat in het seizoen 2017/2018 de provincies via de Wnb geen vergunning meer hebben afgegeven voor additionele toepassing van de rechten voor staande netten voor de wolhandkrabvisserij (de zgn. oranje merken), en dat daarnaast voor de schubvisvisserij in 2018 aanvullende beperkingen zijn ingetreden ten aanzien van meer gesloten gebieden en meer periodes die gesloten zijn voor de staand netten visserij.

Aan de hand van deze beweegredenen kan worden gesteld dat het zeer onwaarschijnlijk is dat de vangstadviezen voor schubvis terug zullen komen op of boven het niveau van voor 2014, m.a.w. dat het zeer onwaarschijnlijk is dat de reductie van $85 \%$ van de vangstinspanning uit 2014 (deels) zal worden teruggedraaid, en dat er nieuwe ruimte zal komen voor de inzet van (een deel van) de $85 \%$ rechten voor staande netten. Daarnaast is ook de verwachting dat rechten voor visserij op wolhandkrab met staand (lage) netten, als gevolg van de beperkingen van de Wnb, naar grote 
waarschijnlijkheid niet zullen worden toegestaan, tenzij kan worden aangetoond dat deze visserij geen of weinig schade berokkent aan de soorten die vanuit de Wnb moeten worden beschermd. Voor de zekerheid zou een overgangsperiode kunnen worden ingesteld van een aantal jaren (5-7). Deze overgangsperiode zou kunnen worden benut om het aantal rechten voor staande netten vast te stellen die tijdens deze periode niet meer zijn toegestaan voor commerciële visserij, en die dus definitief kunnen worden ingenomen. 
1. Het gebruik van rechten voor staande netten en de aantallen ervan wordt gereguleerd via vergunningen (visserijvergunning en Wnb-vergunning). In 2014 is als gevolg van

visbestandsbeheer een reductie afgekondigd van $85 \%$ van de rechten voor de visserij op schubvis. Op grond van de visserijvergunning mag de resterende $85 \%$ van de rechten in principe worden gebruikt voor de staand net visserij op wolhandkrab via lage staand netten. Het is de Wnbvergunning, die via de provincies wordt afgegeven, die bepaalt welke visserij-inspanning en onder welke voorwaarden daadwerkelijk plaats mag vinden.

2. Het innemen van een deel van de rechten voor staande netten wordt conform rechtspraak over artikel 1 Eerste Protocol bij het EVRM gezien als regulering van eigendom en niet als ontneming van eigendom. Bedrijven en resterende rechten behouden hun waarde en kunnen verhandeld worden.

3. Regulering van eigendom is toegestaan onder bepaalde voorwaarden. Eén van de voorwaarden is dat er een 'fair balance' moet zijn tussen het algemene belang en het individuele belang. In veel gevallen is daarvoor enige vorm van compensatie nodig. Een overgangstermijn kan voldoende compensatie bieden om de ondernemer de gelegenheid te bieden de onderneming aan te passen aan de gewijzigde omstandigheden.

4. De langetermijndoelstellingen van het ministerie van LNV voor een duurzaam beheer van de schubvisbestanden in het IJsselmeer zijn gericht op herstel van visbestanden. Hierbij past een visserij-inspanning die gering zal moeten zijn.

5. Provincies toetsen visplannen op de Natura 2000-doelstellingen en worden daarbij steeds kritischer bij het afgeven van een Wnb-vergunning voor de schubvisvisserij. Hierdoor wordt de kans zeer gering dat ooit een visserij-inspanning geadviseerd zal worden die hoger is dan de huidige toegestane inspanning van $15 \%$ ten opzichte van de jaren voor 2014. De mogelijkheid is dus zeer gering dat deze $85 \%$ rechten of een deel daarvan ooit weer mogen worden ingezet.

6. Na de $85 \%$ reductie in het jaar 2014 is er een voorraad netten aanwezig die in een periode van bijna 7 jaar uitgeput zal zijn. Dit houdt in dat bij ongewijzigd beleid de visserijondernemer in het jaar 2021 met nieuwe netten zal moeten gaan vissen. Uitgaande van een ongewijzigde bestaande situatie waarbij na inname van ongebruikte staand net visrechten $15 \%$ hoge en mogelijk ook lage rechten in gebruik mogen blijven, leidt het innemen van de ongebruikte visrechten staand net niet tot inkomens- en vermogenseffecten of disproportionaliteit. De inkomensschade voor vissers bij het innemen van ongebruikt staand netten rechten is nihil.

7. Gelet op al deze publieke en private belangen wordt geadviseerd om bij afkondiging van de maatregel voor het definitief innemen van ongebruikte rechten voor staande netten een overgangstermijn te nemen van 5 tot 7 jaar. De rechten voor staande netten die gedurende deze overgangstermijn commercieel niet meer mogen worden gebruikt, kunnen definitief worden ingenomen. Deze periode biedt aan vissers voldoende gelegenheid om bedrijf en bedrijfsvoering aan te passen; de verminderde visserij-inspanning geldt immers al vanaf 2014 . Mochten gedurende de voorgestelde overgangstermijn van 5 - 7 jaar toch nog aanvullende rechten voor visserij op schubvis (hoog) of wolhandkrab) worden toegestaan, dan zijn die rechten niet meer onbenut, en zullen deze rechten dus ook niet worden ingenomen. Hiermee wordt geborgd dat alleen die rechten die al zeer lange tijd niet meer gebruikt zijn, ingenomen gaan worden. 


\section{Literatuur en websites}

Barkhuysen, T. en M.L. van Emmerik. De eigendomsbescherming van artikel 1 EP EVRM en het Nederlandse bestuursrecht. Jurisprudentie Bestuursrecht plus, 2003.

Hoge Raad. Arrest in de zaak van Nederlandse Vakbond Varkenshouders. ECLI:NL:HR:2001:AD5493, 16 november 2001.

Hoge Raad. Arrest in de zaak van Nederlandse Federatie van Edelpelsdierenhouders. ECLI:NL:HR:2016:2888, 16 december 2016.

Ogink, G.J.A., J.H. Olink en L.F.I. Westerlaken. Evaluatie Wet Herstructurering Varkenshouderij. Onderdeel Milieu. Expertisecentrum LNV, maart 2002.

Raad van State. Uitspraak 201502279/1/A3. Hoger beroep tegen de staatssecretaris van Economische Zaken. 26 april 2016.

Schild, A. De betekenis van artikel 1 eerste protocol voor het ondernemingsrecht. NJCM Bulletin, jrg. 32 (2009), nr 5.

Tien, N.S.H., T. van der Hammen, P. de Vries, E. Schram en J. Steenbergen. Inspanningsadviezen voor snoekbaars, baars, blankvoorn en brasem in het IJssel- en Markermeer. Visseizoen 2017/2018. Wageningen University \& Research Rapport C018/17, IMARES, IJmuiden, maart 2017.

Tien, N.S.H., D.C.M. Miller en B. Griffioen. Inspannings- en monitoringsadviezen voor snoekbaars, baars, blankvoorn en brasem in het IJsselmeer. Rapport C202/13, IMARES, IJmuiden, 10 december 2013.

Overheid.nl, Wettenbank. Visserijwet 1963.

Overheid.nl, Wettenbank. Reglement voor de Binnenvisserij 1985.

Overheid.nl, Wettenbank. Regeling Uitvoering Wet verbod pelsdierenhouderij 2014.

Overheid.nl, Wettenbank. Varkensbesluit, 2005.

Overheid.nl, Wettenbank. Verordening Welzijnsnormen Nertsen (2003).

Zaalmink, B.W., B. Janssens en H. Prins. Economische waarde IJsselmeervisserij. Notitie met betrekking tot de vaststelling van vergunningen en merken. Wageningen Economic Research, Nota 2017-085, Wageningen, oktober 2017. 
Wageningen Economic Research Postbus 29703

2502 LS Den Haag

T 0703358330

Ecommunications.ssg@wur.nl

www.wur.nl/economic-research

Wageningen Economic Research NOTA

2019-006
De missie van Wageningen University \& Research is 'To explore the potential of nature to improve the quality of life'. Binnen Wageningen University \& Research bundelen Wageningen University en gespecialiseerde onderzoeksinstituten van Stichting Wageningen Research hun krachten om bij te dragen aan de oplossing van belangrijke vragen in het domein van gezonde voeding en leefomgeving. Met ongeveer 30 vestigingen, 5.000 medewerkers en 10.000 studenten behoort Wageningen University \& Research wereldwijd tot de aansprekende kennisinstellingen binnen haar domein. De integrale benadering van de vraagstukken en de samenwerking tussen verschillende disciplines vormen het hart van de unieke Wageningen aanpak. 



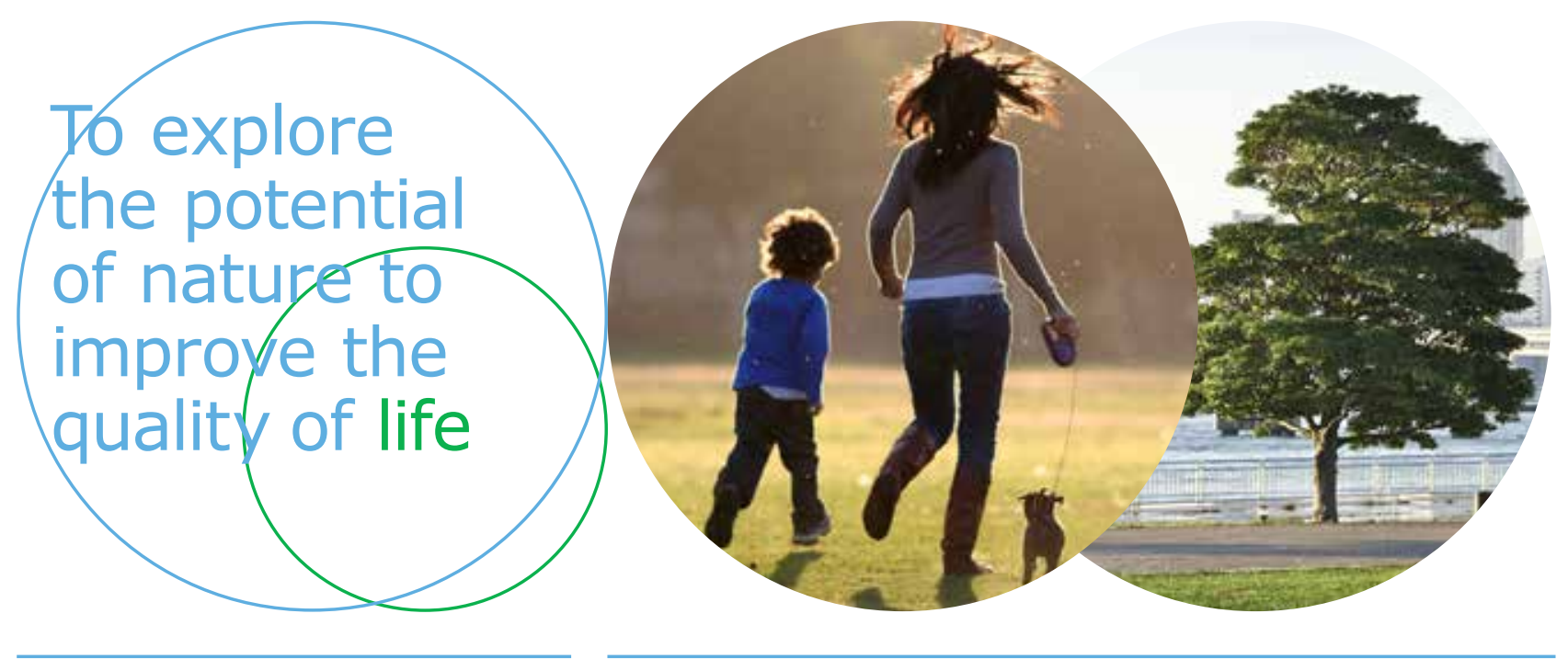

Wageningen Economic Research Postbus 29703

2502 LS Den Haag

E communications.ssg@wur.nl

T +31 (0)7033583 30

www.wur.nl/economic-research

Nota 2019-006
De missie van Wageningen University \& Research is 'To explore the potential of nature to improve the quality of life'. Binnen Wageningen University \& Research bundelen Wageningen University en gespecialiseerde onderzoeksinstituten van Stichting Wageningen Research hun krachten om bij te dragen aan de oplossing van belangrijke vragen in het domein van gezonde voeding en leefomgeving. Met ongeveer 30 vestigingen, 5.000 medewerkers en 10.000 studenten behoort Wageningen University \& Research wereldwijd tot de aansprekende kennisinstellingen binnen haar domein. De integrale benadering van de vraagstukken en de samenwerking tussen verschillende disciplines vormen het hart van de unieke Wageningen aanpak. 